\title{
The Legality Issue of the Financing Contract at the Sharia Rural Banks (BPRS) and the Solution in Sharia Agreement Law Perspective
}

\author{
Isdian Anggraeny'1, Wardah Dinnar Rahmadanti²
}

1Law Faculty, University of Muhammadiyah Malang , E-mail: isdian@umm.ac.id ${ }^{2}$ Law Faculty, Airlangga University, E-mail: wardahdinar@gmail.com

\begin{tabular}{l}
\hline Info Artikel \\
\hline Masuk: 31 ${ }^{\text {st }}$ May 2020 \\
Diterima: $9^{\text {th }}$ September 2020 \\
Terbit: $30^{\text {th }}$ September 2020 \\
Keywords: \\
Agreements; Sharia Financing; \\
BPRS; Compilation of Sharia \\
Economic Law \\
\\
Corresponding Author: \\
Isdian Anggraeny. Email: \\
isdian@umm.ac.id \\
DOI: \\
10.24843/JMHU.2020.v09.i03. \\
p14
\end{tabular}

\begin{abstract}
Sharia-based financing institutions are currently experiencing developments in the financial industry. Sharia financing provided by the BPRS is one of the ways that can be used by the community to meet their daily needs or manage their business. The use of financing certainly has the risk of default and execution of collateral which of course will be detrimental to the creditors (BPRS). Various financing problems are generally caused by the financing process that does not pay attention to legal provisions, especially sharia contract law and guarantee law. Taking the theme: "Issues on the Legality of the Financing Contract at BPRS and its solution in the Perspective of Agreement Law", this paper will examine two problems, namely: First, reviewing the validity of the Sharia financing contract at BPRS based on the Sharia Economic Law Compilation; and second, reviewing and finding the efforts that should be made by the BPRS so that the sharia financing contract meets the pillars and conditions of the contract in the Sharia Economic Law Compilation. This study uses a normative juridical research method with a statutory approach method, concepts, and cases. Through this method, the following findings were obtained: First, the problem of sharia financing in BPRS Syariah lies in the nonfulfilment of the Rukun and the terms of the sharia contract in some of its financing contracts which are dominated by carelessness in applying the legal principles of financing and SOPs that have been made. Second, the BPRS and its Customers must pay attention to and understand the elements of the fulfilment of the pillars and terms of the contract in the financing contract against the rules contained in the Sharia Economic Law Compilation.
\end{abstract}

\section{Introduction}

A bank is a financial intermediary institution that will run well when the public has confidence in the Bank. This trust in the Bank makes the public enjoy the services provided by the bank so that the bank also benefits in the form of a difference in income and interest costs or profit-sharing known as the "spread". ${ }^{1}$ Sharia-based banks

\footnotetext{
${ }^{1}$ Research and Development Center for the National Legal System of the National Law Development Agency of the Ministry of Law and Human Rights of the Republic Indonesia.
} 
/ financial institutions in Indonesia also develop along with the development of shariabased community economic activities so that sharia contract law is also a concern. Sharia-based economic activities do not only develop in Indonesia but also in other countries, such as the United States. As in Noor Mohammed's writings, awareness about Islam in the United States has increased so that the study of Islamic contract law (sharia) is very important in the growth of trade between the western world and Muslims. $^{2}$

The background of the existence of Islamic banking and financial institutions was the recommendation from the Indonesian Ulema Council in Indonesia in 1990. 3 Furthermore, this recommendation was followed up by the Government of Indonesia with the issuance of Law Number 10 Year 1998 concerning Banking. The development of Islamic banking is also supported by the existence of public awareness regarding the prohibition of usury in the view of Islam. Sharia-based economic activities must of course emphasize sharia contract law. Sharia contract law has detailed provisions in ensuring proper business transactions between companies and prohibits usury. ${ }^{4}$ Therefore, Islamic banks must eliminate the elements of usury, gharar, and tadlis, and their operations are adjusted to the concept of fiqh. Therefore, the Islamic bank in Indonesia has become one of the institutions that exist in the community should avoid the element of interest in the system and its operation, especially using a system of profit-taking by way of interest, although it is still a debate among legal thinkers of Islam. ${ }^{5}$

Legally, the definition of Sharia banking is listed in Law Number 21 of 2008 concerning Sharia Banking, namely: everything concerning sharia banks and sharia business units which include institutions, business activities, as well as methods and processes for carrying out their business activities. Islamic financial institutions consist of Sharia Commercial Banks (BUS) and Islamic People's Financing Banks (BPRS). 6 This is also based on Article 18 in Law Number 21 of 2008 concerning Islamic Banking (Islamic Banking Law). Sharia People's Financing Bank (hereinafter referred to as BPRS) is a bank financial institution that carries out economic activities based on sharia principles and structurally under the monetary policy board. Juridically based on Article 1 number 9 of the Sharia Banking Law, a BPRS is a Sharia Bank which in its activities

(2011). Report on Compendium of Banking Law Under the Leadership of Dr. Hj. Siti Sundari Arie, $\mathrm{SH}, \mathrm{MH}$. Jakarta.

2 Mohammed, N. (2015). Principles of Islamic Contract Law. Journal of Law and Religion, 6(1), 115-130. https:// doi.org/10.2307/1051062

3 Anonimous. (2019). Perkembangan Keuangan Syariah di Indonesia - Kompasiana.com. Retrieved October 13, 2020, from kompasiana.com website: https://www.kompasiana.com/dinanaura19/5e048659097f36605d63c0c3/perkembangankeuangan-syariah-di-indonesia

${ }^{4}$ Jalil, A., \& Rahman, M. K. (2010). Islamic Law of Contract is Getting Momentum. International Journal of Busminess and Social Science, 1(2), 175-192. Retrieved from https:// webcache.googleusercontent.com/search?q=cache:gH-

r4y3uRREJ:https://ijbssnet.com/journals/Vol._1_No._2_November_2010/14.pdf+\&cd=1\&hl $=\mathrm{id} \& \mathrm{ct}=\mathrm{clnk} \& \mathrm{gl}=\mathrm{id}$

${ }^{5}$ Maulana, M. (2014). Jaminan Dalam Pembiayaan Pada Perbankan Syariah Di Indonesia (Analisis Jaminan Pembiayaan Musyarakah dan Mudarabah). Jurnal Ilmiah Islam Futura, 14(1), 93. https://doi.org/10.22373/jiif.v14i1.80

6 Dwi Suwiknyo, Analisis Laporan Keuangan Perbankan Syariah, Pustaka Pelajar, Yogyakarta, 2010, Page. 7. 
does not provide services in payment traffic. The existence of BPRS is regulated in the Sharia Banking Law which exists to complement Law Number 7 of 1992 concerning Banking which has been amended by Law Number 10 of 1998 which has not specifically and specifically regulated Sharia Banks. Furthermore, BPRS is specifically regulated in the Financial Services Authority Regulation Number 3/POJK.03/2016 concerning Sharia Rural Banks.

BPRS has several business activities, namely: collecting funds from the public in the form of deposits and investments; distribute funds to the public; placing funds in another Sharia Bank; transferring money through an account of a Sharia (Islamic) People Financing Bank, and providing products or conducting other Sharia Bank business activities following Sharia Principles based on Bank Indonesia approval (Article 21 of the Sharia Banking Law). As the activities of the BPRS in the community develop, the problems faced by the BPRS also develop. These problems have resulted in many BPR/S has to be liquidated by Bank Indonesia each year, even though in 20062014 only 3.33\% of BPRS were liquidated by Bank Indonesia. ${ }^{7}$ One of the main problems often experienced by BPRS is related to financing. The non-performing financing ratio of BPRS is greater than the ratio of non-performing financing for Commercial Banks and Sharia Business Units. ${ }^{8}$ This is because Commercial Banks and Sharia Business Units have better human resources and systems than BPRS. 9 According to the records of the Infobank Research Bureau (birI), the performance of Islamic banking has not improved since 2012, especially on financing issues. ${ }^{10}$ Return on assets (ROA) of Islamic banking has been proven to continue to decline, namely at $2.14 \%$ (2012) continues to decline with a ROA of 0.79 (2014). ${ }^{11}$ Therefore, governance and human resource issues in the BPRS also need to be fixed.

Based on the above financing problems, in principle, financing activities at a BPRS must also use sharia principles, economic democracy, and prudential principles. ${ }^{12}$ This is as stated in Article 26 paragraph (3) of Financial Services Authority Regulation Number 3 / POJK.03 / 2016 which stipulates that the management of a BPRS must comply with the principles of prudence and Sharia Principles. Therefore, the process of making a sharia contract in Islamic banking (in this writing BPRS) must also comply with the pillars and terms of the contract regulated in Islamic sharia. The pillars of the contract that are regulated by Islamic sharia are listed in the Sharia Economic Law

\footnotetext{
${ }^{7}$ Maulana, I. (2017, May 24). Bank Pembiayaan Rakyat Syariah Masih Rentan Bankrut Halaman all, - Kompasiana.com. Retrieved October 13, 2020, from kompasiana.com website: https://www.kompasiana.com/irvanmaulana/5925300a589773be229863c4/bankpembiayaan-rakyat-syariah-masih-rentan-bankrut?page=all,

8 Rostanti, Q., \& Zuraya, N. (2013, October 22). Pembiayaan Bermasalah BPRS Masih Tinggi | Republika Online. Retrieved October 13, 2020, from Replubika.co.id website: https://republika.co.id/berita/ekonomi/syariah-ekonomi/13/10/22/mv266e-pembiayaanbermasalah-bprs-masih-tinggi

9 Ibid

10 Supriyanto, E. B. (2018). Perbankan Syariah: Kinerja yang Buruk karena Tata Kelola. Retrieved August 19, 2019, from infobanknews.com website: http://infobanknews.com/analisis/perbankan-syariah-kinerja-yang-buruk-karena-tatakelola/

11 Ibid

12 Ifham, A. (2010). Pedoman Umum Lembaga Keuangan Syari'ah. Jakarta: PT. Gramedia Pustaka Utama.
} 
Compilation which has been enacted based on the Supreme Court Regulation No.2 of 2008 concerning the Sharia Economic Law Compilation. Therefore, the pillars and terms of the contract have legal firmness and justification in Indonesian law. Thus, the process of making a sharia contract at a BPRS also needs to pay attention to the harmonious contract according to Article 22 Compilation of Sharia Economic Law which consists of parties who have a contract, the object of the contract, the main purpose of the contract, and agreement. ${ }^{13}$

In principle, if the financing contract meets the pillars and terms of the contract set out in the Sharia Economic Law Compilation, the financing contract is ideal and provides legal protection for each party in the contract. However, in practice in the community, financing problems are still often found which originates from financing contracts. As happened in BPRS X Malang, which often experienced problems in the implementation of financing contracts, such as defaults by BPRS debtors and difficulties in executing collateral. This of course will worsen the condition of BPRS X Malang over time. Therefore, this problem attracts the author's attention to further analyze the sharia financing contract which is a source of law for creditors and debtors.

Various financing problems occur because the financing process does not pay attention to legal provisions, especially sharia contract law and guarantee law. Based on the author's observations, some of the financing contracts in BPRS X do not meet the pillars and terms of the financing agreement stipulated in the Sharia Economic Law Compilation. Several samples of contracts totaling 32 financing contracts at BPRS X Malang which have been analyzed by the author, of the 32 samples there are 20 financing contracts which indicate that the debtor did not have a guarantee strengthening deed at the time the financing contract was carried out and among them also did not meet one / several pillars and requirements. contract. Therefore, this study will identify and analyze various matters related to the legal principles of work agreements with several problem formulations as follows: First, how is the validity of the Sharia financing contract at a BPRS based on the Sharia Economic Law Compilation? Second, what efforts should the BPRS have made so that the sharia financing contract meets the pillars and conditions of the contract in the Sharia Economic Law Compilation?

In connection with the idea of this study, it is known that previous research discusses the following matters: the application of the principles of sharia in the Murabaha financing contract at the muamalat bank ${ }^{14}$, the compliance of the Murabaha contract sharia in the concept of financing in Islamic banking in Indonesia ${ }^{15}$, and the analysis of Islamic law on the implementation of the Murabaha contract in BPRS 16. Based on

${ }^{13}$ Muhammad Kamal Zubair, \& Hamid, A. (n.d.). Eksistensi Akad dalam Transaksi Keuangan Syariah. Jurnal Hukum Diktum, 14(1), 46. Retrieved from http://almaiyyah.iainpare.ac.id/index.php/diktum/article/view/222

${ }_{14}$ Makkulau, A. R., \& Abdullah, M. W. (2017). Penerapan Prinsip Syariah Dalam Akad Pembiayaan Murabahah Pada Bank Muamalat. Jurnal Iqtisaduna, 3(1), 60. https://doi.org/10.24252/iqtisaduna.v3i1.4032

${ }^{15}$ Roficoh, L. W. (2019). Kepatuhan syariah akad murabahah dalam konsep pembiayaan pada perbankan syariah di indonesia. Human falah: Jurnal Ekonomi Dan Bisnis Islam, 1(6), 54-68. Retrieved from http://jurnal.uinsu.ac.id/index.php/humanfalah/article/view/2447

16 Tayono, T., Fefriadi, R., Azas, I., \& Adiano, C. (2016). Analisis Hukum Islam Tentang Pelaksanaan Akad Murabahah Di Bpr Syariah. Mimbar Keadilan, 0(0), 139-146. Retrieved from http://jurnal.untag-sby.ac.id/index.php/mimbarkeadilan/article/view/2214 
previous studies that have been described above, there has not been any research that discusses the problem in fulfilling the validity of the financing contract at the BPRS and the solution from the perspective of Sharia Agreement Law. This juridical analysis of the sharia financing contract aims to find the efforts that should be made by the BPRS so that the sharia financing contract meets the pillars and conditions of the contract in the Sharia Economic Law Compilation.

\section{Research Methodology}

This research is a normative juridical legal research because it wants to examine the two legal products, namely the financing contract at the BPRS and the Compilation of Islamic Economic Law. The approach method used in this research includes 1) The statutory approach, namely by examining statutory regulations ${ }^{17}$ relating to sharia financing contracts; 2) Conceptual approach, namely by examining and understanding concepts; 3) Case Approach, namely by examining cases related to legal problems faced in this study. ${ }^{18}$ Furthermore, legal material analysis techniques are arranged systematically using an interpretation system, such as grammatical interpretation and systematic interpretation.

\section{Results and Discussion}

\subsection{Validity of Sharia financing contracts at BPRS based on the Compilation of Islamic Economic Laws}

The sharia-based financial industry that has developed in various countries currently faces more complex and broader legal challenges than conventional-based financial industries. ${ }^{19}$ This of course also applies to Indonesia, which is a country-oriented towards western law at the beginning of independence so that some of its legal rules are still conventional based, especially in the scope of civil law which generally uses the Civil Code. Therefore, with a much longer history of conventional-based financial practices and embedded infrastructure, it is a challenge for the sharia-based financial industry ${ }^{20}$, both in terms of legal application and settlement of disputes. Moreover, the doctrine of freedom of contract, which is the latest trend in contract making, has become a point of dispute among fiqhi scholar ${ }^{21}$ so that in-depth studies regarding the development of sharia contracts are needed.

Several problems arise as a result of the process of sharia financing at BPRS. In this study, the author takes data from the BPRS Malang City. This problem arises due to the creditors' negligence in carrying out the Sharia financing procedures. There are also

\footnotetext{
17 Peter Mahmud Marzuki. (2017). Penelitian Hukum: Edisi Revisi (Cetakan ke). Jakarta: Kencana.

${ }^{18}$ Ibrahim, J. (2007). Teori dan Metodologi Penelitian Hukum Normatif. Malang: Bayumedia.

${ }^{19}$ Ercanbrack, J. (2019). The Standardization of Islamic Financial Law: Lawmaking in Modern Financial Markets. The American Journal of Comparative Law, 67(4), 825-860. https://doi.org/10.1093/ajcl/avz010

$20 \mathrm{Ibid}$.

${ }^{21}$ Abdullah, A. (2011). The Doctrine of the Freedom of Contract (Hurriyyat al-Ta'āqud) in Islamic Mu'âmalāt: An exposition on the concept and rules of the contract of muqāwalah in the construction industry on JSTOR. Islamic Studies, 50(3/4), 365-381. Retrieved from https://www.jstor.org/stable/41932602?seq=1
} 
errors from debtors who do not know the financing procedures and legal consequences they get after signing the sharia financing contract. This causes the financing process to be not transparent and does not fulfill the harmonious conditions and conditions of the contract based on the Sharia Economic Law Compilation, especially on the elements of the agreement. ${ }^{22}$ Negligence of a creditor (in this case the BPRS) is undergoing a financing procedure that may harm the creditor itself. Losses for creditors can be seen from financing that is not under the terms and conditions of the contract based on the Sharia Economic Law Compilation.

Credit financing is supposed to follow Standard Operating Procedures which are based on the fulfillment of the pillars and contract requirements listed in Chapter III of the Sharia Economic Law Compilation. The pillars of the contract, namely: the parties to the contract, the object of the contract, the main objective of the contract, and the agreement. If these pillars are fulfilled, it will become a valid contract. A valid contract according to the Sharia Economic Law Compilation is a contract that does not contain elements of ghalath / Khilaf, is carried out under ikrah / coercion, taghrir or deception, and ghubn / disguise (Article 29 (1)). Furthermore, the agreed contract must contain the following provisions: the agreement of both parties, the skills of the parties in the engagement, a certain matter, and a cause that is lawful according to Islamic law.

The problem that arises in BPRS Malang City is that creditors are not careful or even deliberately accepting debtors who are fictitious debtors whose names have only been borrowed by other parties. Also, the Creditor accepts collateral objects which do not have valid legal force. For example, no authentic fiduciary deed is made on the collateral object in the form of a car. Conditions like this can make the financing contract become facades / can be canceled or canceled/canceled by law (Article 27 Compilation of Sharia Economic Laws). However, it should be remembered that based on the Sharia Economic Law Compilation, the pillars and conditions of the contract must be fulfilled thoroughly, if one of the pillars of the contract is not fulfilled then the contract is null and void (Article 28 (3)). Elly Erawati and Herlien Budiono stated that the sharia contract is null and void because an agreement has never been born from the beginning, and thus there has never been an agreement. ${ }^{23}$ Meanwhile, a Sharia contract that can be canceled is a contract that is harmonious and the conditions are met, but defects that can eliminate the willingness or will of some other parties, such as coercion and mistakes. Cancellation of the contract, of course, makes it difficult for the creditor to collect or execute the collateral object which is still in the possession of the debtor.

Based on the results of the study, there are several bad credit problems when the Islamic People's Financing Bank provides credit financing to prospective borrowers. Problems that arise are caused when the making of a financing contract is not based on procedures, such as there is no agreement between married couples in the Sharia financing contract, the debtor's documents are incomplete; There is no third party approval as the owner of the collateral object, in which the guarantee object is not in the name of the debtor, the guarantee is not equipped with an authentic deed such as

\footnotetext{
22 Interview with Nurhayati. Debtor at PT. BPRS Bumi Rinjani, Malang. On February 27, 2018.

${ }^{23}$ Erawati, E., \& Budiono, H. (2010). Penjelasan Hukum tentang Kebatalan Akad syariah. Jakarta: Nasional Legal Reform Program.
} 
the fiduciary security deed and the deed of the imposition of mortgage rights so that legally the guarantee does not have executive power. ${ }^{24}$

For the various problems above, it is necessary for the author to present an analysis of the elements of the fulfillment of the terms and conditions of the BPRS financing contract based on the harmonious contracts in the Sharia Economic Law Compilation, namely as follows:

\subsubsection{Fulfillment of the financing terms of parties who have contracted/the ability of the parties}

The parties to this contract must meet the skills of the party making the engagement. The Sharia Economic Law (in any country) states that the parties to the contract must have and meet legal qualifications and be competent. ${ }^{25}$ The parties that enter into a Sharia financing contract are individuals, groups of people, associations, or business entities (Article 23 (1) The Sharia Economic Law Compilation). People acting as legal subjects in the contract are required to be legally competent, sensible, and tamyiz (Article 23 (2) Compilation of Sharia Economic Law). The fulfillment of the pillars and conditions of this contract is indicated by the ability to fulfill the identity of the parties conducting the contract. According to the law, all legally competent persons can take legal actions, including making a sharia contract. A person is said to be legally competent when the person is an adult or has been married. The age limit for maturity in the Sharia Economic Law Compilation is at least 18 years old (Article 2). However, a person who is not yet 18 years old can apply for recognition of his legal capacity to take legal action to the court (Article 3).

Based on the results of the research, it shows that there is a financing contract that does not include the identity of the prospective debtor. Whereas the Standard Operational Procedure of PT BPRS X Malang (research location) determines the existence of documents that must be fulfilled, namely the personal documents that are submitted when the application for financing is made, such as Identity Cards, Family Cards, and others. The sample of the financing agreement that the author examined did not include the identity of the debtor, such as the National Identity Card, Family Card, Marriage Certificate book, and other file deficiencies as included in a financing contract note. This of course leads to procedural defects, because in a financing process in the banking sector, complete debtor documents should be completed. This serves to see the skills of the parties who carry out the sharia contract and ensure that the debtor can carry out the sharia contract following Article 2 of the Sharia Economic Law Compilation.

If one or both parties to the sharia contract are incapable of acting in a contract, there will be juridical consequences as regulated in Article 28 which will cause the contract to be null and void.

\footnotetext{
${ }^{24}$ Data is processed from 32 (thirty wo) samples of PT. BPRS Bumi Rinjani Malang City on Fulfillment of Legal Requirements for Sharia Agreement in Article 22 of the Sharia Economic Law Compilations

${ }^{25}$ Shamsuddin, Z., Ghafar Ismail, A., Sultan, U., Abidin, Z., \& Terengganu, K. (2013). Agency Theory in Explaining Islamic Financial Contracts. Middle-East Journal of Scientific Research, 15(4), 530-545. https://doi.org/10.5829/idosi.mejsr.2013.15.4.2361
} 


\subsubsection{Fulfillment of the contract financing in terms of the object of the contract / certain things contract}

The sharia must clearly state the object of the contract so that there is legal certainty for the parties. The object of the contract is amwal legalized or services required by each party (Article 24 The Sharia Economic Law Compilation). The object of this contract is related to items or achievements that must be fulfilled. This has the same substance as the object of the contract in Islamic law, but Islamic law requires that the object of the contract must be able to be translated according to syara'. ${ }^{26}$ According to the term jurist, Syara 'is the effect desired by the syar'i book on actions such as obligations, prohibitions, and permissions. ${ }^{27}$ Achievements in sharia contracts must be certain or at least can be determined. Provisions The clarity of the object of the agreement is needed in fulfilling achievements (rights and obligations). This means that an agreement must have a principal object (object) of which the type can at least be determined so that the object can be identified in the agreement. Also, the agreement must regulate certain matters, namely the rights and obligations of each party.

This was also conveyed by Sudikno Mertokusumo, who stated that achievement is what is the debtor's obligation and what is the creditor's right. ${ }^{28}$ Meanwhile, regarding the object of the agreement, Salim HS, stated that the object of the agreement is the achievement (the principal of the agreement) which must be determined, permitted, possible, and can be valued in money.29 In Islamic law, something that is used as the object of the contract (Mahallul 'Aqd) already exists when the contract is carried out, is justified by sharia, must be recognized, and must be able to be handed over.

In an engagement to give something, the object to be given to the other party must be certain. In a Sharia financing contract, the object of the agreement is in the form of financing (money) from the BPRS. Furthermore, to strengthen the position of the BPRS in the process of providing financing, the debtor provides a certain object to the creditor for a financing guarantee. This is because the creditor is obliged to bear the financing issued to the debtor. The creditor will fulfill the debtor's obligations and receive the right to collect from the previously agreed upon material.

Sharia contract that occurs in the financing contract at PT. BPRS X Malang is an effort by the BPRS to provide fees to customers who experience a lack of funds in project financing or other needs. The risk belongs to the Sharia Bank and BPRS in the financing provided by each Sharia Bank and BPRS to its customers. ${ }^{30}$ Therefore, this financing requires a guarantee for the security of the creditor. Thus, the creditor provides

${ }^{26}$ Damaitu, E. R. (2014). Perbandingan asas perjanjian menurut Hukum Islam dan menurut Kitab Undang-Undang Hukum Perdata. Repertorium, 1, 61-67. Retrieved from https://media.neliti.com/media/publications/212969-perbandingan-asas-perjanjian-dalamhukum.pdf

${ }^{27}$ Mustafa, Z. (2013). Determinasi Al-Ahkam Al-Syar'iyah dalam Tradisi Hukum Islam. Al Daulah: Jurnal Hukum Pidana Dan Ketatanegaraan, 2(1), 29-37. https://doi.org/10.24252/AD.V2I1.1421

${ }_{28}$ Mertokusumo, S. (1987). Hukum Acara Perdata Indonesia. Yogyakarta: Liberty.

${ }^{29}$ HS, Salim. (2003). Hukum Kontrak, Teori dan Teknik Penyusunan Kontrak. Jakarta: Sinar Grafika..

${ }^{30}$ Kartika, R. F. (2016). Jaminan Dalam Pembiayaan Syariah (Kafalah Dan Rahn). Kordinat 1 Jurnal Komunikasi Antar Perguruan Tinggi Agama Islam, 15(2), 229-252. https://doi.org/10.15408/kordinat.v15i2.6332 
financing to the debtor and the debtor provides collateral following the size of the loan given by the creditor. This is also following the provisions of the OJK in the Circular on Products and Activities of Sharia Rural Banks which states that BPRS can ask for guarantees from customers at the time of distribution of financing. ${ }^{31}$

The sample of the contract is 32 financing contracts (Murabaha contract) which the authors have analyzed. Murabaha contract is a transaction of buying and selling goods at the acquisition price plus profit (margin) agreed between the seller and the buyer where the seller informs the buyer of the purchase price in advance. ${ }^{32}$ Of the 32 samples, 20 financing contracts show that the debtor does not have a guarantee strengthening certificate at the time the financing contract is executed. Sharia financing provided by BPRS is intended to fulfill project financing / other needs requested by prospective debtors. To guarantee this financing, the Debtor provides guarantees to the BPRS. This guarantee provided aims to avoid the risks borne by BPRS33, one of which is the delivery of fiduciary guarantees. But in fact, the provision of fiduciary guarantees for Sharia Financing provided by BPRS is not carried out following legal procedures as stated in Articles 11-12 of Law Number 42 of 1999 concerning Fiduciary Security (hereinafter referred to as the Fiduciary Guarantee Law). At 20 (twenty) sample of financing contracts that use motorized vehicle guarantees, it is identified that there is no transfer of property rights in the form of a fiduciary guarantee deed that is made authentically. An authentic deed is a deed made by or in front of an official appointed by law and has perfect evidentiary power. ${ }^{34}$ The high cost of making authentic deeds and fiduciary registration are the reasons the creditor does not follow the legal procedures of the Fiduciary Guarantee, especially since the financing requested by the Debtor is of small value. ${ }^{35}$ In the end, they only used an underhand fiduciary guarantee deed drawn up by the BPRS. This of course makes the fiduciary deed has no legal force as stipulated in Article 15 of the Fiduciary Law. Moreover, the basis is that this is not following the Standard Operating Procedure of PT BPRS X Malang City which has stipulated that the form of binding for movable objects must be adjusted to the applicable legal provisions in the form of a fiduciary guarantee deed. ${ }^{36}$

Also, the problem that arises in Sharia financing in BPRS is that the debtor guarantees motorized vehicles that are not legally owned by the debtor. Ownership documents are not in the name of the debtor himself. Standard Operational Procedure PT BPRS X Malang City has determined that there must be a Cessie, either under-hand deed or Authentic deed, for collateral on behalf of another person used by the Debtor. The two problems mentioned above have legal consequences for the creditor, namely the

\footnotetext{
${ }^{31}$ Nasyi'ah, I., \& Chusna, A. J. (2012). Implementasi Prinsip Syariah Terhadap Penyitaan Jaminan Fidusia. Journal de Jure, 4(2), 147-159. https:/ / doi.org/10.18860/j-fsh.v4i2.2984

32 Rosyadi, I. (2017). Jaminan Kebendaan Berdasarkan Akad Syariah. Depok: Kencana.

33 Standard Operating and Financing Procedures of PT. BPRS Bumi Rinjani, Malang. Year 2014.

${ }^{34}$ Nasyi'ah, I., \& Chusna, A. J. (2012). Implementasi Prinsip Syariah Terhadap Penyitaan Jaminan Fidusia. Journal de Jure, 4(2), 147-159. https:/ / doi.org/10.18860/j-fsh.v4i2.2984

${ }^{35}$ Interview with Mr. Rudy Achmad Triongko. Head of PT. BPRS Malang Branch. March 2, 2018

${ }^{36}$ Standard Operating and Financing Procedures of PT. BPRS Bumi Rinjani, Malang. In 2014 in Chapter VIII concerning the Binding of Financing or Receivables stated that the form of collateral binding must be done by applicable legal provisions of the type of collateral to be bound, including movable objects: Fiduciare Eigendoms Overdraft (FEO).
} 
difficulty in executing the fiduciary object if the debtor does not want to hand over the fiduciary security object.

\subsubsection{Fulfillment of the financing contract in terms of the main objective of the contract/cause which is lawful according to Islamic Sharia.}

The main objective in the Sharia contract is the fulfillment of life needs and business development for the parties bound by the contract (Article 25 (1)). The subject matter in a sharia contract must consist of subject matter, namely: the object of the contract, goods, commodities, and considerations (money, goods, or services), all of which must be halal ${ }^{37}$ Of course, the main objective of the contract is closely related to the reasons/reasons for the origin of the Sharia contract. The reason for the initial creation of the sharia contract is the main objective of the contract. In this case, the parties must determine the reasons for the establishment of a lawful Sharia contract, namely that it does not contradict Islamic law, statutory regulations, public order, and/or morality (Article 26). In addition to being based on the Sharia Economic Law Compilation, because halal is also listed in Article 1335-Article 1337 of the Civil Code which is essentially in line with what has been determined in the Sharia Economic Law Compilation.

In the Sharia financing contract at PT BPRS X Malang City, there was an event of borrowing the name as a debtor in the financing contract. This incident is known through the existence of two financings under the name of the debtor and the date of the same application. However, later on, the sharia financing contract became a problem. Based on the data obtained in the field, the debtor does not know that in one of the credit financing, his name is listed as the debtor. The debtor only knows when a financing application is promised a faster, easier process, and does not use collateral. The sharia using a nominee arrangement contract is completely unknown in the Indonesian legal system, especially in contract law in general so that it does not get legal protection for the party whose name is borrowed as a debtor. Unless, the incident constitutes bad faith or dishonesty from one of the BPRS employees, and of course the debtor who feels aggrieved over the borrowing of the name must be able to prove the employee's bad faith. The agreement by borrowing a name certainly fulfills the provisions of Article 26 of the Sharia Economic Law Compilations so that the contract becomes invalid and can be null and void.

\subsubsection{Fulfillment of the agreement in the financing contract}

The agreement is the essence of an agreement that contains an offer and acceptance. Offer and acceptance are the main signs that indicate the commitment of Islamic law to consesualism. ${ }^{38}$ An agreement is a meeting of the will of each party regarding the things that are desired to be implemented or fulfilled. This agreement creates a legal relationship in the form of rights and obligations (achievements) between each party. The birth of the agreement must be based on the existence of freedom by the parties in the sharia contract. The agreement occurs when the party's wishes have been

\footnotetext{
37 Shamsuddin et all, Op.Cit

38 Minarosa, M. (2018). The Principles of International Trade Contract as Reference of Indonesian Contract Law. In European Research Studies Journal.
} 
understood and accepted explicitly by the opposing party by observing the principle of prudence based on customary law that lives in society. ${ }^{39}$ This is in line with the theory of an agreement, namely: The Theory of Will, The Theory of Statements, and The Theory of Belief.40

According to Islamic law, the agreement is expressed in terms of consent and qabul (Sighat al-'Aqd). There are 3 (three) things that must be done in making the consent qabul to have legal consequences, including 1) the objectives contained in the statement are clear, 2) there is compatibility between consent and qabul, and 3) between consent and qabul must show the will the parties are certain, there is no doubt whatsoever, are not under pressure, and are not under pressure. ${ }^{41}$ Furthermore, Article 29 of the Sharia Economic Law Compilation states that an agreement is valid if it is given without any elements of ghalath or error, carried out under ikrah or coercion, tahjrir, or deception and ghubn or disguise. The agreement is the manifestation of the will of the parties in the sharia contract to be implemented, how to implement it, when it must be implemented, and who must carry it out. If someone signs a sharia contract, then that person declares that he is willing to be bound by a sharia contract that he has signed. Signing has several functions, including identification and statement of the will of the parties involved in the sharia contract.

The agreement is declared invalid in the Sharia Economic Law Compilation, namely if the agreement is reached because of an error or was made by coercion or fraud. Statements of intent are mostly carried out by the parties in perfect language orally and writing. The purpose of making a written sharia contract is to provide legal certainty for the parties and as perfect evidence when a dispute occurs in the future. The agreement is valid if it is not due to the mistake, not coercion, or not because of fraud (articles 30-34).

PT. BPRS X has Standard Operating Procedures in providing financing to customers. However, in its implementation, there is a mismatch between the Sharia financing contract and the Operational Standard of PT BPRS X. Among the 32 Sharia financing contracts that were analyzed in this study, as many as 26 financing contracts did not have complete signatures from the parties of the contract, either partially or in part. one of the parties. The existence of signatures of the parties is a sign of the parties' agreement in a formal form on paper, whether made in the form of an underhanded agreement or an authentic agreement. Also, regulations related to signatures have become part of the BPRS Standard Operating Procedures. Article 11 Standard Operational and Financing Procedures for PT. BPRS X Malang City Year 2014 in Chapter VIII concerning Bonding of Financing or Receivables stipulates that every implementation of a financing / receivable contract must include the signature of the bank and the customer as well as the signature of the married couple and witness by a

${ }^{39}$ Anggraeny, I., \& Al Fatih, S. (2020). Kata Sepakat Dalam Perjanjian Dan Relevansinya Sebagai Upaya Pencegahan Wanprestasi. DE LEGA LATA: Jurnal Ilmu Hukum. https://doi.org/10.30596/dll.v5i1.3446.

${ }^{40}$ Budiono, H. (2010). Ajaran Umum Hukum Perjanjian dan Penerapannya di Bidang Kenotariatan. Bandung: Citra Aditya.

${ }^{41}$ Sari, N. R. (n.d.). Komparasi Syarat Sahnya Perjanjian Menurut Kitab Undang-Undang Hukum Perdata Dan Hukum Islam. Jurnal Repertorium, 4(2), 83. Retrieved from https://jurnal.uns.ac.id/repertorium/article/viewFile/18284/14486 
minimum of two witnesses who are adults according to law. applicable law. However, when the process of the Sharia financing agreement at PT BPRS X Malang had not yet completed the signatures of the parties, the BPRS continued to disburse funds to prospective debtors. Associated with the importance of a signature as a form of agreement between the parties in the sharia financing contract, when the Sharia financing contract is not complete, it can be said that there is no agreement from the signed party or the nature of proof is weak (in the end the agreement is in oral). This indicates that the BPRS has made a mistake and does not apply the prudential principle in the application of the Standard Operating Procedure for Financing PT. BPRS X Malang City. This condition can certainly be detrimental to PT. BPRS X Malang City as a creditor when there is a default by the customer.

\subsection{Efforts to Fulfill the Pillars and Conditions of the Contract in the Sharia Financing Contract}

Based on the practical point of view, most creditors make a sharia financing contract unilaterally related to the contents of their sharia financing contract. In this case, the Debtor is only given the option to approve the contents of the sharia financing agreement or reject the contents of the contract. Rejecting the contents of a sharia financing agreement means not following up on a proposal for financing at the BPRS. Because the contents of the financing contract are made by only one party/creditor (standard agreement), of course, the contract has the potential to be burdensome to the other party/debtor. The imbalance in the standard agreement in the financing agreement can be exploited by a bank with a stronger position to tend to make the contents of the clause according to the bank's wishes in the form of reducing the rights and increasing the applicant's obligations and increasing the rights and reducing the bank's obligations. ${ }^{42}$ The contract only states the obligations of one party (the debtor), while the rights of that party (the debtor) are not stated. 43

Based on the Sharia Economic Law Compilation, a Sharia contract can be canceled (a façade contract) or legally canceled (a canceled contract) if it fulfills Article 28 (2) and Article 28 (3). A façade contract is a Sharia contract that fulfills the terms and conditions of the contract, but there are several aspects or other things that damage the contract. Meanwhile, a contract that is canceled is a Sharia contract that is not harmonious and / or the terms and conditions. Thus, the pillars and terms of the contract are the main things in evaluating the quality of the Sharia contract. These terms and conditions for the contract are implemented in Article 29 (2) Compilation of Sharia Economic Law, which requires the contract to fulfill 4 conditions as explained in the point above. Also, the Sharia financing contract must comply with the sharia principles as outlined in Article 2 paragraph (2) of Bank Indonesia Regulation Number 10/16/Pbi/2008 concerning Amendments to Bank Indonesia Regulation Number 9/19/Pbi/2007. 44 The provisions of Bank Indonesia Regulation Number

${ }^{42}$ Lubis, Z. Z. S. E., Nur, M., \& Sanusi, S. (2019). Asas Keseimbangan dalam Perjanjian Penerbitan Letter of Credit Sebagai Transaksi Bisnis Internasional. Jurnal Magister Hukum $\begin{array}{lllll}\text { Udayana (Udayana Master } & 261 .\end{array}$ https://doi.org/10.24843/jmhu.2019.v08.i02.p09

${ }^{43}$ Sjahdeini, S. R. (1993). Kebebasan Berkontrak dan Perlindungan Yang Seimbang Bagi Para Pihak Dalam Akad syariah Kredit di Bank di Indonesia. Jakarta: Institut Bankir Indonesia.

${ }^{44}$ Fidhayanti, D. (2014). Perjanjian Baku Menurut Prinsip Syariah (Tinjauan Yuridis Praktik 
10/16/Pbi/2008 have also been replaced by Article 2 POJK Number 10 /POJK.05/2019 concerning the Implementation of Sharia Financing Company Businesses and Financing Company Sharia Business Units which essentially have the same provisions that: " The implementation of Sharia Financing activities must comply with the principles of justice ('adl), balance (tawazun), benefit (maslahah), and universalism (alamyah) and should not contain gharar, maysir, usury, zhulm, risywah, and haram objects."

Guided by the provisions of the contract in the Sharia Economic Law Compilation and sharia principles above, the solution can be given so that the financing contract at PT. BPRS X Malang can fulfill sharia principles and legal requirements of sharia contracts, so it is necessary to do the following efforts:

First, to recognize and understand the parties that will be bound by the Sharia contract. Each party, both creditors and potential debtors must both recognize and understand the identity of the other party. The identification of the parties can be started by looking at the identity of the party (original) issued by the authorized institution. Based on this identity, it can be seen how the position of each party in acting. With an identity, it will also be known the ability/authority of a person to carry out an action that will be stated in the Sharia financing contract, starting from rights, obligations to the accountability of parties. The entirety of this must be based on the parties' documents which indicate the position of each party.

Identity must pay attention to the type of legal subject acting. If the person acting is a human legal subject, the required identification documents, such as Identity Card and/or Passport, Family Card, and marriage certificate. If the person acting is a legal subject in the form of a legal entity, the required entity identity documents, such as the deed of establishment of a legal entity, legal entity decree, deeds of amendment from that legal entity, and/or other business licenses. In addition to ensuring the authority/position of a person is acting in law, this fulfillment of personal identity also aims to explain the domicile address of a prospective Debtor for execution purposes when the debtor defaults.

Second, the direct presence of the party applying for financing. The party that will apply for financing to the BPRS should have personally come (prospective debtors) to the BPRS office. Creditors must apply the principle of prudence in researching and identifying prospective debtors that a prospective debtor is a person who acts on himself in the financing. The presence of the Debtor is directly part of good faith and makes it easier for Creditors to assess Debtor Capacity. The self-assessment of the prospective debtor in providing financing can help fulfill the terms of the agreement which is free from fraud and errors. It is also useful for creditors to carry out credit analysis, such as seeing the ability of prospective borrowers to make financing. Thus, the financing contract can be avoided by fraud. Like wise for Prospective Debtors, although Prospective Debtors need the role of Creditors in assisting them, Prospective Debtors must also know that the representative of the Creditor (BPRS) is indeed the person authorized to represent the BPRS.

Third, the fulfillment of documents as a requirement for applying for Islamic financing. The documents required by the Creditor for the Prospective Debtor, namely the form

Pembiayaan di Perbankan Syariah). Journal de Jure, 6(2), 133. https://doi.org/10.18860/jfsh.v6i2.3206 
of financing application, guarantees that have been transferred by Notary, and Identity Card. If the Prospective Debtor is a Business Entity with a Legal Entity, the required documents are a copy of the articles of association, Company Registration Certificate, Trading Business License, Taxpayer Identification Number, financial statements, and other licensing documents. About these documents, the debtor must show the original documents to the BPRS to avoid fraud. These documents serve as creditor information for the prospective debtor to analyze the amount of the loan based on the potential debtor's ability to return the loaned financing.

Fourth, Creditor's understanding of the object of guarantee and guarantee legal procedures. The collateral object is a guarantee for creditors in providing financing to debtors. Collateral is a measure of a Debtor customer's wealth / financial capacity which can be used as a form of creditor confidence, either in the form of cash collateral or collateral in the form of fiduciary and mortgage. ${ }^{45}$ This is also confirmed in Article 1 paragraph (26) of Law Number 21 of 2008 stipulating that guarantees from debtor customers are very urgent for Islamic Banks. A guarantee is a form of legal protection for the Creditor / BPRS when the Debtor commits one of the default actions or even when the Debtor runs away until the Creditor does not have the assets to demand payment from the Debtor.

Therefore, creditors / BPRS needs to understand legal procedures in various forms of guarantees, each of which has different procedures and types of objects. The parties, especially creditors, must make a sharia financing contract that accommodates the existence of laws and regulations related to the object of guarantee and understands the legal consequences of not accommodating these laws and regulations. Such as a form of guarantee that is often applied by PT. BPRS $X$ to its customers, namely fiduciary security and insurance rights. Fiduciary security and security rights have differences in legal procedures and types of objects. Fulfillment of the correct procedure affects the legality of the guarantee, especially in its execution. If the guarantee procedure has been carried out correctly by the Creditor by statutory regulations, the Creditor can carry out direct execution without going through a court and is final and binding on the parties. In other words, when the debtor defaults and does not have the good faith to settle it, the creditor can execute the collateral as a form of repayment of the debtor's debt.

Fifth, completeness of the signatures of the parties in the sharia financing contract. The sharia financing contract must be made by the parties as if the parties are two legislators and if not, then one party is not obliged to comply with the law (the Sharia financing contract). ${ }^{46}$ As evidence that each of these Parties agrees to all clauses and the correctness of the data contained in the sharia financing contract, each party is obliged to sign his / her signature as a symbol or sign of each party. All parties who put signatures in the contract are legal subjects who will be legally responsible for fulfilling their respective obligations in the contract. Therefore, the signing by the parties must be done immediately by each party when all parties agree on the Sharia financing contract.

Sixth, the application of governance principles for good financing distribution. The implementation of governance principles for disbursement of financing can be started

${ }^{45}$ Maulana, Muhammad. Op.Cit.

46 Ibid. 
with the existence of a Standard Operating Procedure for Financing in a BPRS. However, of course, the Standard Operating Procedures for Financing also need to be upheld in providing services to customers. Principles of the governance distribution of this funding includes the principles of transparency, accountability, responsibility, professionalism, fairness in carrying out activities, and prudence. This is as stated in the provisions of Article 34 and Article 35 of Law Number 21 the Year 2008.

\section{Conclusion}

The issue of sharia financing in the legal aspect of the contract lies in the incompatibility of the sharia contract/financing contract against the pillars and terms of the sharia contract as regulated in Chapter III of the Sharia Economic Law Compilation. The cause of the problem is that the creditor / BPRS has made mistakes and does not apply the principle of prudence in the application of Standard Operating Procedures for Financing and statutory regulations related to sharia financing. This causes several financing contracts to become legally flawed (can be nullified/canceled by law) so that they do not have legal force because they do not fulfill the terms and conditions of the contract. Therefore, efforts need to be made so that the financing contract can protect both parties, namely: 1) recognizing and understanding the parties that will be bound by the Sharia contract; 2) the direct presence of the party applying for financing; 3) fulfillment of documents as a requirement for applying for sharia financing; 4) Creditor's understanding of the guarantee object and guarantee legal procedures; 5) completeness of the signatures of the parties in the sharia financing contract, and 6) implementation of good governance principles.

\section{References}

$\underline{\text { Book }}$

Budiono, H. (2010). Ajaran Umum Hukum Perjanjian dan Penerapannya di Bidang Kenotariatan. Bandung: Citra Aditya.

Erawati, E., \& Budiono, H. (2010). Penjelasan Hukum tentang Kebatalan Akad syariah. Jakarta: Nasional Legal Reform Program.

HS, S. (2003). Hukum Kontrak, Teori dan Teknik Penyusunan Kontrak. Jakarta: Sinar Grafika.

Ibrahim, J. (2007). Teori dan Metodologi Penelitian Hukum Normatif. Malang: Bayumedia.

Ifham, A. (2010). Pedoman Umum Lembaga Keuangan Syari'ah. Jakarta: PT. Gramedia Pustaka Utama.

Mertokusumo, S. (1987). Hukum Acara Perdata Indonesia. Yogyakarta: Liberty.

Peter Mahmud Marzuki. (2017). Penelitian Hukum: Edisi Revisi (Cetakan ke). Jakarta: Kencana.

Sjahdeini, S. R. (1993). Kebebasan Berkontrak dan Perlindungan Yang Seimbang Bagi Para Pihak Dalam Akad syariah Kredit di Bank di Indonesia. Jakarta: Institut Bankir Indonesia.

Suwiknyo, D. (2010). Analisis Laporan Keuangan Perbankan Syariah. Yogyakarta: Pustaka Pelajar.

\section{Journal}

Abdullah, A. (2011). The Doctrine of the Freedom of Contract (Hurriyyat al-Ta'āqud) in Islamic Mu'āmalāt: An exposition on the concept and rules of the contract of 
muqāwalah in the construction industry on JSTOR. Islamic Studies, 50(3/4), 365381.

Anggraeny, I., \& Al Fatih, S. (2020). Kata Sepakat Dalam Perjanjian Dan Relevansinya Sebagai Upaya Pencegahan Wanprestasi. DE LEGA LATA: Jurnal Ilmu Hukum. https://doi.org/10.30596/dll.v5i1.3446

Damaitu, E. R. (2014). Perbandingan asas perjanjian menurut Hukum Islam dan menurut Kitab Undang-Undang Hukum Perdata. Repertorium, 1, 61-67. Retrieved from https://media.neliti.com/media/publications/212969-perbandingan-asasperjanjian-dalam-hukum.pdf

Ercanbrack, J. (2019). The Standardization of Islamic Financial Law: Lawmaking in Modern Financial Markets. The American Journal of Comparative Law, 67(4), 825-860. https://doi.org/10.1093/ajcl/avz010

Fidhayanti, D. (2014). Perjanjian Baku Menurut Prinsip Syariah (Tinjauan Yuridis Praktik Pembiayaan di Perbankan Syariah). Journal de Jure, 6(2), 133. https://doi.org/10.18860/j-fsh.v6i2.3206

Jalil, A., \& Rahman, M. K. (2010). Islamic Law of Contract is Getting Momentum. International Journal of Busminess and Social Science, 1(2), 175-192. Retrieved from https:/ / webcache.googleusercontent.com/search?q=cache:gH-

r4y3uRREJ:https://ijbssnet.com/journals/Vol._1_No._2_November_2010/14.pdf+ $\& c d=1 \&$ hl $=\mathrm{id} \& \mathrm{ct}=\mathrm{clnk} \& \mathrm{gl}=\mathrm{id}$

Kartika, R. F. (2016). Jaminan Dalam Pembiayaan Syariah (Kafalah Dan Rahn). Kordinat | Jurnal Komunikasi Antar Perguruan Tinggi Agama Islam, 15(2), 229-252. https://doi.org/10.15408/ kordinat.v15i2.6332

Lubis, Z. Z. S. E., Nur, M., \& Sanusi, S. (2019). Asas Keseimbangan dalam Perjanjian Penerbitan Letter of Credit Sebagai Transaksi Bisnis Internasional. Jurnal Magister Hukum Udayana (Udayana Master Law Journal), 8(2), 261. https://doi.org/10.24843/jmhu.2019.v08.i02.p09

Makkulau, A. R., \& Abdullah, M. W. (2017). Penerapan Prinsip Syariah Dalam Akad Pembiayaan Murabahah Pada Bank Muamalat. Jurnal Iqtisaduna, 3(1), 60. https:/ / doi.org/10.24252/iqtisaduna.v3i1.4032

Maulana, M. (2014). Jaminan Dalam Pembiayaan Pada Perbankan Syariah Di Indonesia (Analisis Jaminan Pembiayaan Musyarakah dan Mudarabah). Jurnal Ilmiah Islam Futura, 14(1), 93. https:/ / doi.org/10.22373/jiif.v14i1.80

Minarosa, M. (2018). The Principles of International Trade Contract as Reference of Indonesian Contract Law. In European Research Studies Journal.

Mohammed, N. (2015). Principles of Islamic Contract Law. Journal of Law and Religion, 6(1), 115-130. https://doi.org/10.2307/1051062

Muhammad Kamal Zubair, \& Hamid, A. (n.d.). Eksistensi Akad dalam Transaksi Keuangan Syariah. Jurnal Hukum Diktum, 14(1), 46. Retrieved from http://almaiyyah.iainpare.ac.id/index.php/diktum/article/view/222

Mustafa, Z. (2013). Determinasi Al-Ahkam Al-Syar'iyah dalam Tradisi Hukum Islam. Al Daulah: Jurnal Hukum Pidana Dan Ketatanegaraan, 2(1), 29-37. https://doi.org/10.24252/ AD.V2I1.1421

Nasyi'ah, I., \& Chusna, A. J. (2012). Implementasi Prinsip Syariah Terhadap Penyitaan Jaminan Fidusia. Journal de Jure, 4(2), 147-159. https://doi.org/10.18860/jfsh.v4i2.2984

Roficoh, L. W. (2019). Kepatuhan syariah akad murabahah dalam konsep pembiayaan pada perbankan syariah di indonesia. Human falah: Jurnal Ekonomi Dan Bisnis Islam, $1(6)$, 54-68.

Retrieved

from 
http://jurnal.uinsu.ac.id/index.php/humanfalah/article/view/2447

Rostanti, Q., \& Zuraya, N. (2013, October 22). Pembiayaan Bermasalah BPRS Masih Tinggi | Republika Online. Retrieved October 13, 2020, from Replubika.co.id website: https://republika.co.id/berita/ekonomi/syariahekonomi/13/10/22/mv266e-pembiayaan-bermasalah-bprs-masih-tinggi

Rosyadi, I. (2017). Jaminan Kebendaan Berdasarkan Akad Syariah. Depok: Kencana.

Sari, N. R. (n.d.). Komparasi Syarat Sahnya Perjanjian Menurut Kitab Undang-Undang Hukum Perdata Dan Hukum Islam. Jurnal Repertorium, 4(2), 83. Retrieved from https://jurnal.uns.ac.id/repertorium/article/viewFile/18284/14486

Shamsuddin, Z., Ghafar Ismail, A., Sultan, U., Abidin, Z., \& Terengganu, K. (2013). Agency Theory in Explaining Islamic Financial Contracts. Middle-East Journal of Scientific Research, 15(4), 530-545. https://doi.org/10.5829/idosi.mejsr.2013.15.4.2361

Sjahdeini, S. R. (1993). Kebebasan Berkontrak dan Perlindungan Yang Seimbang Bagi Para Pihak Dalam Akad syariah Kredit di Bank di Indonesia. Jakarta: Institut Bankir Indonesia.

Tayono, T., Fefriadi, R., Azas, I., \& Adiano, C. (2016). Analisis Hukum Islam Tentang Pelaksanaan Akad Murabahah Di Bpr Syariah. Mimbar Keadilan, 0(0), 139-146. Retrieved from sby.ac.id/index.php/mimbarkeadilan/article/view/2214

http://jurnal.untag-

$\underline{\text { Internet }}$

Anonimous. (2019). Perkembangan Keuangan Syariah di Indonesia Kompasiana.com. Retrieved October 13, 2020, from kompasiana.com website: https://www.kompasiana.com/dinanaura19/5e048659097f36605d63c0c3/perkem bangan-keuangan-syariah-di-indonesia

Maulana, I. (2017, May 24). Bank Pembiayaan Rakyat Syariah Masih Rentan Bankrut Halaman all, - Kompasiana.com. Retrieved October 13, 2020, from kompasiana.com website: https://www.kompasiana.com/irvanmaulana/5925300a589773be229863c4/bankpembiayaan-rakyat-syariah-masih-rentan-bankrut?page=all,

Rostanti, Q., \& Zuraya, N. (2013, October 22). Pembiayaan Bermasalah BPRS Masih Tinggi | Republika Online. Retrieved October 13, 2020, from Replubika.co.id website: https://republika.co.id/berita/ekonomi/syariahekonomi/13/10/22/mv266e-pembiayaan-bermasalah-bprs-masih-tinggi

Supriyanto, E. B. (2018). Perbankan Syariah: Kinerja yang Buruk karena Tata Kelola. Retrieved August 19, 2019, from infobanknews.com website: http://infobanknews.com/analisis/ perbankan-syariah-kinerja-yang-burukkarena-tata-kelola/

\section{Report}

Research and Development Center for the National Legal System of the National Law Development Agency of the Ministry of Law and Human Rights of the Republic Indonesia. (2011). Report on Compendium of Banking Law Under the Leadership of Dr. Hj. Siti Sundari Arie, SH, MH. Jakarta.

\section{$\underline{\text { Regulation and Legal Document }}$}

Law Number 10 Year 1998 concerning Banking

Law Number 21 of 2008 concerning Sharia Banking 
Law Number 42 of 1999 concerning Fiduciary Security

The Financial Services Authority Regulation Number 3/POJK.03/2016 concerning Sharia Rural Banks.

The Supreme Court Regulation No.2 of 2008 concerning the Sharia Economic Law Compilation

The Sharia Economic Law Compilation

The Civil Code

POJK Number 10 / POJK.05/2019 concerning the Implementation of Sharia Financing Company Businesses and Financing Company Sharia Business Units

Bank Indonesia Regulation Number 10/16/Pbi/2008 concerning Amendments to Bank Indonesia Regulation Number 9/19/Pbi/2007

Standard Operating and Financing Procedures of PT. BPRS X Malang. In 2014 